\title{
The canon as text for a biblical
}

\section{theology}

\author{
James Alfred Loader \\ Institut für Alttestamentliche Wissenschaft und Biblische Archäologie \\ University of Vienna and Unisa
}

\begin{abstract}
The novelty of the canonical approach is questioned and its fascination at least partly traced to the Reformation, as well as to the post-Reformation's need for a clear and authoritative canon to perform the function previously performed by the church. This does not minimise the elusiveness and deeply contradictory positions both within the canon and triggered by it. On the one hand, the canon itself is a centripetal phenomenon and does play an important role in exegesis and theology. Even so, on the other hand, it not only contains many difficulties, but also causes various additional problems of a formal as well as a theological nature. The question is mooted whether the canonical approach alleviates or aggravates the dilemma. Since this approach has become a major factor in Christian theology, aspects of the Christian canon are used to gauge whether "canon" is an appropriate category for eliminating difficulties that arise by virtue of its own existence. Problematic uses and appropriations of several Old Testament canons are advanced, as well as evidence in the New Testament of a consciousness that the "old" has been surpassed ("Überbietungsbewußtsein"). It is maintained that at least the Childs version of the canonical approach fails to smooth out these and similar difficulties. As a method it can cater for the New Testament's (superior) role as the hermeneutical standard for evaluating the Old, but flounders on its inability to create the theological unity it claims can solve religious problems exposed by Old Testament historical criticism. It is concluded that canon as a category cannot be dispensed with, but is useful for the opposite of the purpose to which it is conventionally put: far from bringing about theological "unity" or producing a standard for "correct" exegesis, it requires different readings of different canons.
\end{abstract}

\section{THE THEOLOGICAL RELEVANCE OF CANON IN HISTORICAL CRITICISM}

It has become more or less common to introduce papers on the canon by a reference to the sprawling literature ${ }^{1}$ since the seventies or, more precisely, since the well-known and widely discussed paper by Brevard Childs delivered

\footnotetext{
${ }^{1}$ E g Dohmen \& Oeming 1992:9.
} 
to the Göttingen congress of the International Organisation for the Study of the Old Testament in $1977 .^{2}$ Although the current interest in canon as a theological and textual issue has certainly been greatly and decisively stimulated by Childs's work, the issue as such and its relevance for theology were neither introduced by him nor were they only his concern. ${ }^{3}$ Since this is not irrelevant for our topic, I propose to begin with some examples to illustrate the point.

1.1. The first is an article by the Lutheran bishop and theologian, Krister Stendahl, given much prominence by Barr in what is arguably his opus magnum, among other things also regarding the canon. ${ }^{4}$ According to Stendahl, the meaning of the Bible for the present can only be determined by employing the canon as a hermeneutical category. Whatever may have been the meaning or meanings of the texts in earlier times, their theological meaning becomes a hermeneutical issue determined by the canonical status conferred upon these texts: ${ }^{5}$

The question as to the meaning of the Bible in the present - as distinguished from the meaning in the past as stated by descriptive theology - receives its theological answer from the canonical status of scripture. It is as canon, and only as canon, that there is a Bible, an OT and NT as well as the whole Bible of the church as a unity.

This statement takes full account of the historical dimension ("descriptive biblical theology"), but makes it clear that canon is a necessary hermeneutical category for understanding the Bible in terms of normative theology ("meaning in the present"). However one may judge his distinction between the two kinds of theology, his strong emphasis on canon as the sole vehicle of biblical meaning for theology is a clear indication that he had already thought the issue through carefully long before Childs did.

\footnotetext{
${ }^{2}$ Mistakenly dated 1978 by James Barr (1983:132); cf Childs's publication, 1978:66-88 (in this case wrongly stated to have been published in 1977 (Barr 1999:618).

${ }^{3} \mathrm{Cf}$ the works of James Sanders written more or less simultaneously with those of Childs (Sanders 1972, 1976 and 1977). This observation is also made by Barr (1999:378) and would probably not be denied by Childs himself, especially not in the light of his wide reading in the history of Old Testament scholarship (e g Childs 1979:30-39, 1985:2-4 and 1994:20-28, 51-74 etc) and in the light of the fact that he appreciates the work of Jepsen on other aspects of the Old Testament canon (Childs 1994:85; cf Jepsen 1949:69-70) and of Stendahl's article quoted below (Childs 1970:19, 224).

${ }^{4}$ Cf Barr 1999:379-380; the article on biblical theology as such also contains a discussion of the significance of canon for biblical theology (Stendahl 1962:428-430).

${ }^{5}$ Stendahl 1962:429.
} 
1.2. Another instance of the importance of the canon for theology was provided several years earlier by the position of Alfred Jepsen in a guest lecture delivered at the University of Heidelberg in 1957. Jepsen (1957) [1968]:265) winds up his argument for the scholarly significance of Old Testament studies within theology in the following way:

Only if the Old Testament is a canon does it belong to the field of Christian theology. But it can only be a canon if somehow God speaks in it. Therefore, only if also today God still speaks to the church in the Old Testament, can there be a legitimate scholarly discipline of Old Testament studies.

This is an unmistakable plea for the theological significance of the Old Testament canon, formulated in such clear-cut terms that the category of canon is made a sine qua non for biblical theology. To me this seems to involve at least three levels of significance: First, canon is that which makes the Old Testament "theological" at all; second, the only way in which the Old Testament can take its place within Christian theology is by being a canon; and third, in the same strain as Stendahl, canon entails God's speaking to people today. The last level does not necessarily mean that God, whether in the past or in the present, only speaks in a canon, but it does mean that a canon of theologically relevant scriptures must communicate what God speaks. This means that Jepsen regarded the canon as the link between the religious writings of ancient Israel and Christian theology, and therefore as that which brings together the ancient text and God's word in the proclamation of the church today. But he developed this relationship with full recognition of the need to integrate classical historical criticism in the process (Jepsen 1957 [1968]:264), as can be seen in the penultimate phase of his argument:

Of course "scholarly" study of the Israelite-Jewish literature and history is possible without any link to theology. But such investlgation bypasses the "Old Testament" as canon of the church. However, there can be no serious study of the canon that does not incorporate strictly historical research, but then: incorporate the latter into itself, not limit itself to the latter.

In claiming the canon for the church and for theology, Jepsen not only did not sieve out historical criticism or relegate it to a minor position on the sidelines, he positively required as indispensable its participation in all theological work on the canon. This runs counter to the picture of historical criticism's lack of 
interest in the canon and its alleged meagre theological relevance (e g Childs $1979: 40,44)$. One of the hallmarks of Childs's foregrounding of the canon is his rejection of historical criticism as an adequate tool for theology (cf Childs $1979: 77^{6}$ ). Although he is adamant that he has nothing in principle against historical criticism and can appreciate its contribution (e g Childs 1979:40), it is not an appropriate tool for theology.

1.3 As far as the interest of historical-critical Old Testament scholarship in the relationship between canon and theology is concerned, we can go even further back, as far as the nineteenth century. In his widely used book on the canon Gerrit Wildeboer says on the very first page: ${ }^{7}$

This [i e, the study within Christian theology of the Old Testament canon] is not superfluous, because the Christian church has with varying intensity, but nevertheless at all times, accepted the leadership of the Jewish sages, and especially Protestant theologians have always meant that this is the most reliable course to follow.

Wildeboer ([1889]1908:2) then continues that the study of canon is "highly important" for theology, precisely because of the necessity to differentiate between the Jewish and the Christian traditions, the two of which stand opposed to each other. In my judgement this is a very perceptive observation, especially to be taken note of at the beginning of the twenty-first century with its emphasis on the common roots of the Jewish and Christian traditions. Precisely because of the shared heritage, the diversity between the two should not be overlooked, and this is nowhere more relevant than in matters canonical. A special book solely on the canon is necessary despite the fact, he says, that it has been widely written about since the first half of the nineteenth century and is treated in "every so-called 'Introduction'" to the Old Testament Wildeboer ([1889]1908:v). That these ideas form the trend-setting perspective of his introductory chapter demonstrates clearly his desire to relate the question of the canon to theology. This is confirmed by the last chapter, in which Wildeboer ([1889]1908:161-162) concludes:

\footnotetext{
${ }^{6}$ This can already be observed in the tenor of his early book, Biblical Theology in crisis (1970:18-20, 34-36).

${ }^{7}$ Wildenboer [1889]1908:1. I use the fourth edition of the book first published in 1889, second edition 1891, third edition 1900, fourth edition 1908; translated into German 1891, English 1895 (by George Foot Moore), and French 1901. Interestingly, Childs knows and refers to the English translation.
} 
The sages themselves were not totally aware of this canon they have factually created. The school tradition was to come later, the theory was to follow after the actual practice, doctrine after the practice of life.

Seen in the context of his argument that the Lutheran and the Calvinist positions on canon were different since the Reformation or at least since the post-Reformation orthodoxy, it is clear that he conceived of the historicalcritical study and use of the canon not only as highly significant for, but also as motivated by theology.

But Wildeboer also raised another aspect of the canon issue that came to be vigorously discussed in the debate around Brevard Childs and James Barr (cf Barr 1983:49ff and passim; 1999:378-451). He argues that the Lutheran tradition about the canon shows a better understanding of the issue of the canon than the Calvinist tradition, notably that the "problematic question of the canon" ("het Kanonvraagstuk") is not only a theological, but also a historical matter. In this context he sympathetically refers to the German orthodox theologian, David Hollaz I, whose views on the canon, according to Wildeboer, well summarise the orthodox Lutheran view: ${ }^{8}$

Catalogus librorum canonicorum non est articulus fidei.

A list of canonical books is not an article of the faith.

In this declaration we can see at the same time what "canon" meant in orthodox Lutheranism (and, one may add, in proto-pietism as well as in pietism itself): a list of authoritative books, not a final text. Wildeboer noticed that this was an essential issue in the main currents of European Protestantism. The Lutheran confessions never mention the names of the canonical books individually, whereas that is exactly what the Calvinist confessions do, while at the same time classifying them in different canonical groupings or categories. ${ }^{9}$

\footnotetext{
${ }^{8}$ Hollaz (1648-1713) was a classic orthodox Lutheran theologian from northeastern Germany. For his students in Kolberg, Hollaz wrote a summary of received Lutheran theology, Examen theologicum acroamaticum universam theologiam thetico-polemicam complectens, which saw no less than eight editions; Wildeboer ([1889]1908:159) quotes from the second edition 1718, but the first had already appeared in 1707 and the eighth was published in 1763). This work however also contained elements of what was to develop fully in Pietism, and both his son David II (†1738) and his grandson David III (†1771) became full-blown pietist theologians, the former a pupil of Zinzendorf and the latter a representative of Herrnhut theology (cf Gummelt 2000:1844). David I also entertained aspects of natural theology (Pelikan 1947:253-263).

${ }^{9} \mathrm{Cf}$ for example, the Gallican Confession, Art III (1559), the Belgic Confession, Art IV (1562) and the Westminster Confession, Art II (1647).
} 
1.4 This calls for explanation. In Protestant theology the canon became a necessary theological concept since the introduction of the so-called Scripture Principle of the Reformation (reformatorisches Schriftprinzip). This was the Protestant alternative to the Roman Catholic view summed up in the declaration of Gabriel Biel (1410-1495): ${ }^{10}$

The meaning of what the Bible says can easily be distorted. Whatever conclusions are inferred from Holy Scripture, only entail probable opinions that are never so certain that those people who wish to interpret Scripture in their own interest cannot contradict them. In such instances the Pope must decide what Holy Scripture really says.

In the Roman Catholic tradition, the locus of authority was clear: the episcopal church, incorporated in the Pope, determined what was Word of God.

Therefore it is not surprising that no ecumenical council has ever found it necessary to demarcate or fix a biblical canon. But the Reformation did away with the Roman Catholic view of the church (and/or its bishops). The question of authority could only be settled by filling the vacuum. This was done by the Reformation principle of sola Scriptura. What was new was not a Scriptural principle (which had been there for centuries), but its being made exclusive: the locus of authority lies only in the Bible. Since actual practice could not refute Biel's point that the interpretation of Scripture needs a norm, only one possibility remained: in terms of the principle of sola Scriptura the norm had to be within the Bible itself.

Here the Lutheran and the Calvinist traditions followed different ways. For Luther the instrument to regulate the interpretation of Scripture was the principle, "was Christum treibet". In other words, that which proclaims Christ, became the yardstick to determine the truth within Holy Scripture. Not any proclamation of Christ was authoritative, not even an ecclesiastical one, but only that in the Bible which proclaimed him, was. Therefore, while the Lutheran tradition did need a canon, it did not need to demarcate its boundaries in any theologically significant way. Where such highly critical things can be said of biblical books as in Luther's pronouncements on the Book of Esther, the Epistle of James and others, this should be obvious. On the one hand Luther could leave books in the canon despite being of the opinion that they should not really be there, and on the other hand he could keep so-called "Apocrypha", such as 1 Maccabees, which - as opposed to 2 Maccabees - he valued highly, out of the canon. He even created an intermediary status for certain biblical books he regarded as inferior by retaining but not numbering them and having them separated from the rest by

\footnotetext{
${ }^{10}$ Cited according to Kraus 1969:9.
} 
a clear unprinted space ${ }^{11}$. Whether one agrees with Luther or not, the hermeneutical principle that allowed him to work with the canon in this way was a clear and unmistakable criterion functioning as a canon within the canon, and thereby serving as a norm within the canon. Therefore I do not think it deserves to be called an "arbitrary and individualistic tendency within Luther's exegesis", as it is labelled by Childs (1979:44).

The Calvinist current had a different way. Calvin himself did not labour the point. He merely worked with the units called Old and New Testaments (Institutes 7, 1), although he did leave some books uncommented upon. However, the books he appeals to as Scripture, are those of the New Testament and the Hebrew Old Testament, that is, what became the Protestant canon. For him, the authority of the Bible lay in the inspiration of the Holy Spirit in the reading of Scripture (Institutes 1, 5):

Let it be taken as certain that those who are inwardly taught by the Holy Spirit, acquiesce implicitly in Scripture; and that Scripture, carrying as it does its own evidence within itself, does not condescend to submit to proofs and arguments, but owes the full conviction with which we should receive it, to the testimony of the Spirit. ... The only true faith is that which the Spirit of God seals in our hearts.

It is therefore no surprise that the Calvinist tradition developed the idea of the testimonium Spiritus Sancti to perform the function of Luther's rule of faith. But this testimony is closely linked to Scripture - it takes place when the written word of the Bible is read. Accordingly, the locus for the working of the Spirit is the reading of a specific collection of books and therefore the definition of the collection became important. Thus the canon is understood as a collection of books built up with specific units within a specific periphery. Such formal definitions became creedal formulas and are found in the Calvinist, but not in the Lutheran confessions. In the table below I illustrate this with the text of the Gallican Confession, Article III in the column on the left (emphasis my own), and the text of the Belgic Confession, Article IV, in the column on the right. It will be noticed that the Belgic Confession is even clearer than the Gallican in its circumscription of the divisions and subdivisions of the canon:

\footnotetext{
${ }^{11}$ These are the New Testament Epistle to the Hebrews, the Epistle of James, the Epistle of Jude and the Book of Revelation, and remained so presented from the 1522 edition to the last one in 1546; cf Bornkamm 1948:158-161 and passim, as well as Bardtke 1964:85-88, the latter of whom concludes his essay on the topic by himself illustrating the effect of Luther's principle, "was Christum treibet".
} 
These Holy Scriptures are comprised in the canonical books of the Old and New Testaments, of which the number is as follows [desquels le nombre s'ensuit]:

The five books of Moses, namely: Genesis, Exodus, Leviticus, Numbers, Deuteronomy

then [item] Joshua, Judges, Ruth, the first and second books of Samuel, the first and second books of the Kings, the first and second books of the Chronicles, otherwise called Paralipomenon, the first book of Ezra; then Nehemiah, the book of Esther, Job, the Psalms of David, the Proverbs or Maxims of Solomon; the book of Ecclesiastes, called the Preacher, the Song of Solomon;

then the book of Isaiah, Jeremiah, Lamentations of Jeremiah, Ezekiel, Daniel, Hosea, Joel, Amos, Obadiah, Jonah, Micah, Nahum, Habakkuk, Zephaniah, Haggai, Zechariah, Malachi;
We believe that the Holy Scriptures are contained in two books, namely, the Old and New Testaments, which are canonical, against which nothing can be alleged. These are thus named in the Church of God.

The books of the Old Testament are:

The five books of Moses, namely, Genesis, Exodus, Leviticus, Numbers, Deuteronomy

the books of Joshua, Judges, Ruth, the two books of Samuel, the two of the Kings, two books of the Chronicles, commonly called Paralipomenon, the first book of Ezra, Nehemiah, Esther, Job, the Psalms of David, the three books of Solomon, namely, the Proverbs, Ecclesiastes, and the Song of Songs;

the four great prophets, Isaiah, Jeremiah, Ezekiel, and Daniel;

and the twelve lesser prophets, namely, Hosea, Joel, Amos, Obadiah, Jonah, Micah, Nahum, Habakkuk, Zephaniah, Haggai, Zechariah, and Malachi.

\section{Those of the New Testament are:}

then the Holy Gospel according to St Matthew, according to St Mark, according to St Luke, according to St John;

then the second book of St Luke, otherwise called the Acts of the Apostles

then the Epistles of St. Paul: one to the Romans, two to Corinthians, one to the Galatians, one to the Ephesians, one to the Philippians, one to the Colossians, two to the Thessalonians, two to Timothy, one to Titus, one to Philemon;

then the Epistle to the Hebrews, the Epistle of St James, the first and second Epistles of St Peter, the first, second, and third Epistles of St John, the Epistle of St Jude;

and then the Apocalypse, or Revelation of St John the four Evangelists, namely, Matthew, Mark, Luke, and John;

the Acts of the Apostles;

the fourteen epistles of the apostle Paul, namely, one to the Romans, two to the Corinthians, one to the Galatians, one to the Ephesians, one to the Philippians, one to the Colossians, two to the Thessalonians, two to Timothy, one to Titus, one to Philemon, and one to the Hebrews;

the seven epistles of the other apostles, namely, one of James, two of Peter, three of John, one of Jude; and the Revelation of the apostle John. 
Whereas Calvin also made remarks of a critical nature on matters of the authorship of certain books (e $\mathrm{g}$ in the preface to his commentary on Joshua, cf Kraus 1969:17), he nevertheless also retained these books in the canon. But the orthodoxy that followed, came to need the canon not just as the locus for the inspiration of the reader, but as an inspired object. Therefore the canon could no longer be seen as a list of various books with the same status, but became a single, evenly inspired and therefore unbroken text.

My argument thus far has endeavoured to illustrate that the category of canon has always been a natural ingredient in Protestant theology and that it therefore is not surprising to find that, before the rise of the canonical movement in the seventies, both Lutheran and Calvinist scholars were stressing its importance for theology. The Protestant principle of Scripture required it, and within Protestantism it was the Calvinist tradition that had to develop the idea of canon as text. The typical Lutheran theology of Law and Gospel worked with canon as a much looser network of certain texts in the Old Testament that could be seen as "Law" and other texts in the New that could be seen as its counterpart, notably "Gospel". The typical Calvinist orientation, on the other hand, required the canon of the Bible to be seen as a clearly defined and interconnected text.

\section{THE PHYSICAL ASPECT}

But a canon in this sense could not have existed in the early church and certainly not in Jewish tradition up to that time. Without going into the debate of the Hebrew canon versus the Alexandrian or whether the canon antedated Christianity (cf Sundberg 1964 and 1975:356, Schäfer 1975:116-124, Hanhart 1984:400, Steins 1996:251-252), there is also a much more obvious, physical case to be made for the impossibility of a canon in the sense of a Holy Writ in late pre-Christian and the early Christian times. ${ }^{12}$ How could a work too extensive to fit on one scroll, have been conceived of as a single book?

2.1 It seems to me that the physical realities of bookmaking do have a role in the question what a canon in the sense of a book, that is, a connected text, is. Only since the $4^{\text {th }}$ century CE did the codex begin to replace the papyrus or parchment scroll (rotolus, מגלה), which nevertheless still remained in use for

\footnotetext{
${ }^{12}$ Barr (1983:57) briefly refers to this issue as a "small, almost physical, point" (my italics). Apart from its being quite physical, its being so simple is not tantamount to its being minor. On the contrary, its simplicity makes it very powerful and the fact that it has thus far scarcely played a role in the debate all the more surprising. I have devoted a short discussion to it in a paper on the Old Testament as a single book, delivered at the Von Rad centenary celebrations in Heidelberg, 2001 (the volume of this section of papers appeared when this article was already in the press: Loader 2005), as well as a paragraph in an article in this journal on the question of the identity of the Tenach and the Old Testament (Loader 2002b:1418-1420).
} 
several centuries more. ${ }^{13}$ It is scarcely imaginable that, in pre-Christian times and well into the Christian era, "a" book could consist of a number of scrolls sorted into shelf-cubicles or standing upright each in its own box-compartment or individually wrapped in cloths (panuelae) and stored in jars. Such a scroll library could perhaps be perceived as a "canon" in the sense of a collection of several books entered into a list of authoritative writings. But a collection of books (ספרים) written on scrolls (מגלות) could hardly have been regarded as a "canon" in the sense of an inherently structured text or a self-contained book of fixed composition. Moreover, ספר meant "scroll" in late pre-Christian and early Christian times and therefore was synonymous with מגלה 14 . That being the only known notion of a book, it is difficult to see how the Old Testament redactors themselves, the later sopherim, the owners or the readers of anything like the Torah scroll, or that of Isaiah or the Twelve or the Psalms or the collection called the Five Megillot par excellence, could have thought of the one they were reading and all the others in their boxes as a formally unified book.

2.2 The idea of the library character of these writings remained unchanged even after the introduction of the codex. Despite their being committed to pages and bound between hard covers, they were still handed down as so many books. Throughout the centuries the Jewish and Christian traditions have been speaking, and still do, of 39 (or, depending on different combinations, of 22 or 24) books. The Masoretic tradition has preserved precise data specific to each book and has collected them at the end of each separate book, thereby confirming that, despite all that it has in common with others, each book remains an independent ספר. This remains the case even if these colophons were primarily intended as safeguard for the correct form of the text.

2.3 The designations used to refer to the collection in both Jewish and Christian traditions point in the same direction. The Jewish name תנד is an acronym for three groups of books, namely: תורה and נביאים and (Tתובים (Torah, Prophets and Writings). The term ta biblíiilia (Books), handed down further in the Christian tradition, is also plural. Both prevent or at least counter the possibility of allowing the respective alternative terms (המקרא, "reading", "that

\footnotetext{
${ }^{13}$ The earliest known dated codex is the Calendar of Filocalus (354 CE), and the oldest extant codices originally containing the whole Bible, Codex Vaticanus and Codex Sinaiticus, are both from the fourth century.

${ }^{14}$ Kühlewein 1984:166: inscription, document, letter, book; the construct-combination מגלת-ספר occurs in the Old Testament itself (Jr 36:3,4; Ezk 2:9; Ps 40:8).
} 
which is read", "vocalisation", "biblical passage", and $h$ "grafh,, "that which is written", "a piece of writing", "a [specific] sacred text") ${ }^{15}$ to be understood as a single-text canon. Thus "Scripture" is a thinkable concept, but predominantly understood as a plurality of many books rather than as a unity composed as one book.

From these considerations the conclusion seems to flow that not literary issues, but the external bundling of the Old Testament writings in the form of many pages in one jacket suggested the idea that we here have to do with a single book. This may not be a very welcome idea in most canonoriented circles, but it is difficult to believe that the Bible ever could have been seen as one book without such a book that could be seen at all. The initial stages of the canonical process within what we call the Hebrew Old Testament seem to point in the direction of a "tendency to enlarge the field of the protected, revealed literature" (Dohmen \& Oeming 1992:88), and this too suggests the idea of canon as a collection of books and not as one text ${ }^{16}$. This would remain the case even if Steins (1996:252) is right in his conclusion that "the Hebrew canon is older than Christianity and was received as such by it". At best this would have been a pigeonholed wall stuffed with many rolled-up books.

But then, since the fourth century of the Christian era, came the codex. Having gradually developed from only a waxed-over wooden tablet, it was introduced and used as a form of notebook already in the second century, and in the following two centuries became a paged parchment collection. Tied and jacketed, it could hold many sheets suitable to be scripted on both sides.

Because it could hold a far greater volume of text than conventional scrolls, it presented itself as the ideal form to collect extended texts that were associated with each other. Hence the law codices such as the famous Codex Justinianus.

\footnotetext{
${ }^{15} \mathrm{Cf}$, among many, Sot 5:2, Snh 34a for מקרא and Lk 4:21, Jn 7:38 for $h^{`}$ grafh,, (often in the Fourth Gospel and Paul, but rare in the Synoptics). An alternative rabbinic form is also plural: כתבי הקדש, "the Holy Scriptures" in the sense of either the books of the Hebrew canon (e g Mishnah Yadayim 3:5) or the Writings/Hagiographa of the Third Division (e g Tosephta Shab 12:1), which is represented by the plural form grafai algiai in the New Testament (Mt 21:42; Lk 24:27; Ac 18:24; Rm 1:2).

${ }^{16} \mathrm{Cf}$ the slightly diverse formulations of the "canon formula" in Dt 4:2, 13:1, Jr 26:2, $\operatorname{Pr} 30: 6$, prohibiting subtraction and/or addition to God's commandment/words, which makes sense when the extent of a canonical collection is at stake, not the text of a book. No wonder Childs does not expect much from a study of this formula for our understanding of the topic (Childs 1990:357). Cf also Dohmen \& Oeming (1992:86-87), who include Ecc 3:14 in their list of the "canon formula" within the Old Testament (?).
} 


\section{The canon as text for a biblical theology}

\section{THE JACKET AND THE TIE}

Now the Bible could be seen. So it was seen as one object, and therefore it had the possibility to also be seen as one text. This is not the place to consider the vicissitudes of the codexed Bible in the intervening centuries, but the point I am arguing is that the presence of a bound book was necessary for the idea of a canon to be able to develop from a list or index of authoritative books. ${ }^{17} \mathrm{~A}$ common aspect of many books, such as inspired holiness on the one hand or theological and moral impurity on the other, is highlighted by listing them, much in the same way as the sapiential onomastica of the ancient Near East endeavoured to point out that things hang together. A canon in the sense of a list is only necessary because there are many books. Once a book in its entirety could lie on the table, it could also contain many books of the older model. That to which the canon refers, could be put between covers, and this meant more than only referring to, it meant containing the full contents of the canon. So it was also called "canon". But even so it was primarily a complete collection, not a composed book.

3.1 When for theological reasons it became necessary or useful to stress the unity of the books, including theological polemics, it became increasingly crucial to highlight the aspects of its perceived composition. The most obvious is the division between the parts before and after Christ, the two Testaments. But within them other traditional groupings could be pointed out to constitute the text. In the Roman Catholic tradition, the Vulgate appropriation of the Hellenistic Jewish or Septuagint list was continued, and in the Protestant tradition a hybrid between the Septuagint-Vulgate and the rabbinic Hebrew lists was compiled. But this had nothing to do with any inner-canonical network of meaning detected in the one and preferred to the other. It was a matter of general theological rejection of the Roman Catholic position, based as it was on the authoritative tradition of the church, in favour of another principle of authority. But the preference for one and rejection of the other canon was not based on theological interpretation of the canonical network as a text.

It could have been argued, for instance: The fact that the Hebrew canon of the Old Testament counted and grouped the so-called "Historical Books" of the Catholic tradition as the "Former Prophets", can be interpreted as theologically highly significant, notably that these were prophetic in a very

\footnotetext{
${ }^{17}$ The concept is also illustrated by its negative counterpart, of which the infamous Index librorum prohibitorum (1559) of Pope Paul IV is probably the best known. In the Roman Catholic Church such catalogues began with the first ecclesiastical Index under Pope Paul III (1543), but other authorities in Europe had already begun the practice earlier and continued it parallel with the church, e g Henry VIII in England (1526), Dutch catalogues since 1524, and several lists published in Paris since 1544, Louvain 1546, Valencia 1551 and by the English Queen Mary 1555. The interesting aspect of these indices of the Reformation period is that they only became necessary as a result of the invention of printing and the proliferation of books.
} 
special theological sense. The Former and the Latter Prophets are both prophetic in that the former present the history of Israel as it is intervened in and accompanied by God, whereas the latter present the preaching of the prophets about that very involvement of God in history, both of them based on the teaching of the preceding Torah. This can be seen as evidence that the Hebrew view of prophecy is different from the Greek: Prophecy in the former is the proclamation of God's will for his people in actual historical reality and his concomitant intervention in this history. But the Septuagint-Vulgate tradition separates the historical books from the prophetic books by the "poetic" books. A canonical-theological argument is possible that this can be understood according to the scheme: basic revelation (Torah) - past (Historical Books) - present (Poetic and Wisdom Books) - future (Prophetic Books), which could be reinforced by pointing out that the apocalyptic book on the future, Daniel, is included among the prophets only in this tradition. So prophecy in a Hebrew canonical context is a matter of God's involvement in the actual social, political and religious life of his people in history and the application in this life of his will in the Torah. But in a Septuagint-Vulgate canonical context it is a matter of foretelling and of the future of God's people. Such considerations would have constituted "theology in a canonical context", but none of it is found in the theological debates of the Reformation.

\subsection{It may now be asked: What canon is really the canon of the} Reformation? How do we account for a canon with the extent of the Hebrew canon but with the structure of the Septuagint-Vulgate canon? Is this canon not a polemical accident? Polemical in rejecting the Roman Catholic canon as a product founded on the authority of the fathers and the church, and an accident in accepting Jerome's idea of hebraica veritas under the influence of the Renaissance slogan ad fontes but ignoring a vital aspect of it and therefore disjointing the major theological pattern and the subsumed networks in it? If one, therefore, practises canon-critical theology on an explicit Protestant (and Calvinistic) ticket as Childs does, one is faced with the simple fact that such a "theologically significant" canon never existed and still does not exist. There is no single book consisting of the Hebrew canon and the New Testament. So, with what canon does one work and why is the Old Testament not recast in the "correct Hebrew" shape, the theologically highly significant form it is supposed to have $?^{18}$ Are recent developments perhaps pointers that another canonical reconstruction is on its way? Or, by the same token, if one proceeds from a Roman Catholic perspective as Zenger and his colleagues do (Zenger [ed] 1996 etc), how can one be content with claiming

\footnotetext{
${ }^{18}$ The question could be added: If the canonical shape is the one that makes all the difference, why does Childs not model his theologies on the canon (cf Barr 1999:395ff)?
} 
the high significance of canon and "final form", all the while stressing the importance of the "Holy Scripture [singular!] of the [sic!] Jews" - and then treat some of them in their Hebrew canonical shape (with practically no or no relevant recourse to the Septuagint-Vulgate canon used for setting out the rest of the work), but others in their Greek shape whether there is a Hebrew text known or not? This kind of canon never existed either. The same question may be put to canonists in the Roman Catholic fold: What canon are they really using $?^{19}$

3.3 This is the point where we still find ourselves. The canon is there. Or is it? Certainly some canons are there or were there at some point in history. Several have been construed through the centuries and it seems as if this tendency has not stopped at the Reformation, but is fermenting today on all sides of the confessional spectrum - at least where the Old Testament is concerned. Let us - for brevity is the soul of wit - just speak of "the" canon, even though meaning "each respective" canon. The canon is there. It (or each of them) has the form of a book, and this book as a unified text seems to continue fascinating its readers. It is used and its character as a text is appealed to for developing theological arguments. In its Christian use it does contain two Testaments, the second of which cannot be ignored by a theology claiming to be Christian in any way. And its use as canon seems likely to remain with us (cf Barr 1999:438).

What is to be done with it in the light of the problems pointed out above? I submit that both the Protestant and the Roman Catholic perspectives sketched are wrought with deep tensions and deeply contradictory positions. The canon seems to call these forth. But can it be otherwise if the canon itself is wrought with inner tensions and contradictory positions? Can an approach be used to smooth these out if the approach itself is characterised by the same bumpiness? Let us consider the nature of the problematic compendium we have once we start theologising with the canon as a connected text. There are those problems I have already pointed out, further problems of a formal nature, and problems as a matter of content. I shall advance some of these in a representative way.

\section{SCRIPTURE IN THE LIGHT OF SCRIPTURE?}

Some difficulties are of a formal nature and others are more closely concerned with the contents of the passages in the canon(s). We begin with the formal ones.

\footnotetext{
${ }^{19}$ See Paragraph 4 below for further complications in the same strain.
} 
4.1 Declaring the "final form" of the text to be the canon (or vice versa), which is to be the basis for theology - that is, the text to be used for determining the theological meaning of the Bible - is a declaration that Scripture is to be understood in the light of Scripture. Although the canoncritical approach did introduce a whole new orientation, this basic assumption is not a new principle, as most Protestant theologians, particularly in the Calvinist tradition, will know very well. When a theological difficulty crops up in one place, it can be "compared" with a differing view of the matter in another canonical passage, meaning: it can be relativised. Although relativism is usually a very bad thing in theology of this kind, in the Bible it is accepted under labels such as "balance", "equilibrium" or "creative tension". Wishing to overcome the uncertainties and theological ambivalence uncovered and precipitated by historical criticism, it appeals to variety/variance in order to remove the same. In my opinion this kind of driving out the devil with Beelzebub itself is a major inconsistency within canon-oriented theologising. But it creates several more difficulties for itself, difficulties at least as serious as those it blames on the historical-critical heritage and seeks to overcome.

4.2 Seeing the texts within the canon as reciprocal agents for understanding does not necessarily have to work with canon as a holistic literary category. The theological use of Scripture in the rabbinic tradition works precisely the other way round. Not the final text or form or shape of the canon, but individual texts are used to support an argument. That means, they are drawn into a new network, the context of the theologoumenon or theological case being argued. The context of a passage taken from the Bible is not the canonical context, but the new context being created by the theologian. This is also the way in which texts from the Old Testament are recontextualised in the New Testament. Not even the immediate context of such a passage or verse or expression is of importance, let alone the canonical context.

Explaining the three major trends identified by Jacob Neusner in classical rabbinic Bible interpretation, Zahavy (1994) characterises this kind of exegesis as follows:

Many works of classical rabbinic exegesis share common strategies toward the texts of the Bible. Midrash tends to atomize a canonical text and to associate with each segment in order one or more interpretive remarks. These may be alternate or contradictory explanations, expansions or even entirely independent traditions. 


\section{The canon as text for a biblical theology}

In other words, the units of the biblical text signify, not within their literary context and even less within their canonical context, but within the context of the theological argument they are drawn into. According to Neusner (1990) there are three trends: exegetical, propositional, and narrative. Especially the second trend illustrates that the theological excurses are "anchored" in successive biblical verses, as Zahavy puts it, but that entails the recontextualising of the atomised biblical text in the propositional rabbinic argument. This is even more obvious when the order is inverted, starting with a theological statement that leads to an exegesis of the text.

This handling of texts can be seen in the New Testament as well. An illustration is the way a specific Old Testament text is illustrated by Jesus' application of Psalm 82:6 to his proposition, "I am the Son of God" (Jn 10:3436):

Jesus answered, Is it not written in your law, "I said, you are gods"? If it calls those to whom the word of God came, gods - and the scripture cannot be annulled - can you say that the one whom the Father has sanctified and sent into the world is blaspheming because I said, "I am the Son of God"?

Whether "Scripture" ( $h$ `grafh,) here means Scripture generally or this specific text from the Psalms is not of material consequence, since Jesus defends the theological proposition by using a single text from the Old Testament. He does so with recourse neither to the verse's immediate literary context in the Psalm, nor to its compositional context in the Book of Psalms, nor to its canonical context. What is on the canonical index cannot be annulled, so this verse must be true and therefore can be used to support his initial independent theological proposition.

Another example is the use of Psalm 41:10 to confirm Jesus' earlier words on the one who would betray him and to buttress the premise that Judas's impending betrayal is part of God's plan (Jn 13:18):

I am not speaking of all of you; I know whom I have chosen. But it is to fulfil the scripture, "The one who ate my bread has lifted his heel against me."

The literary character of the Psalm as an individual lament plays no role, neither does the fact that it is not a prediction of anything. The text is 
incorporated into a discourse on an exception to the relationship between Jesus and his followers. ${ }^{20}$

I can see no way in which the fact that texts from the Old Testament used like this in the New Testament can contribute to their mutual meaning in terms of the canon as a text. A claim of Jesus, received as a theologically blasphemous claim to the apotheosis of a human, cannot enhance the "textuality" of a poem working in the in the opposite direction, namely on the de-apotheosis, so to speak, of a pantheon of gods and their harmful work. Neither can I see how an individual supplication of a person who is treated unjustly in illness and a narrative on Jesus washing the feet of his disciples enhance each other as aspects of one connected text. But I can see how a verse from one of the authoritative books of the (nascent) Jewish canon could make sense as a propositional foundation for an argument within a religion accepting all of those texts as authoritative. I can also see how a psalm on the nothingness of other gods can make sense for Christians, not because of its literary link to a part of the New Testament, but because they believe Jesus Christ as the Son of God is not an empty idol. Interpreting the psalm "in the light of the New Testament" therefore does not mean "comparing Scripture with Scripture" or balancing parts of a connected text with other parts, but appropriating the reading of a specific text under the impact of the faith informed by the whole of the other. For a Christian it would perhaps be safer to speak of reading the Old Testament in the light of Christ than in the light of the New Testament. The alternative seems to me to be perhaps more sophisticated than the system of dicta probantia prevalent in Protestant orthodoxy, but not much different in essence.

Other difficulties concern the theological contents of the passages appealed to or related to others within the canonical ambit:

\subsection{One such category concerns "wrong" exegesis. What if an} interpretation of an Old Testament text in the New is plain wrong? What sense would it make to relate the two threads of Matthew 1:23 and Isaiah 7:14? A whole register of problems arises in this famous case. One can say that Matthew uses $h$ ' parqe, noj, "the virgin", as proof of Jesus' virgin birth because he simply quotes from the Septuagint, which translated the Hebrew בתולה, "young woman", in this way. Of course this is so, but the Septuagint is wrong. In terms of the idea of canon as a connected text, it brings us nowhere. Unless, of course, we abandon the Hebrew canon altogether and follow Augustine by sticking to the Septuagint canon, but that would also mean departing from the Hebrew canon so vigorously defended by Childs as the very root of his whole approach. Then nothing remains of the Christian canon as a connected text anyway. But one can argue that the Matthew text proclaims in its own right that what one professes with the Nicene Creed

${ }^{20}$ Cf further Jn 17:12; 19:24; 28, 36f; Rm 4:3; 9:17; 10:11; 11:2; GI 3:8; 22; 4:30; 1 Tm 5:18; 2 Tm 3:16; Jm 2:23; 4:5; 1 Pt 2:6 etc. 


\section{The canon as text for a biblical theology}

"according to the Scriptures" has always been the will of God, and that it is of no consequence (for this matter) that in Isaiah there is talk of a sign provided by a pregnant young woman to the king of Judah in his reluctance to trust God in military matters.

4.4 Another category concerns Old Testament passages used critically in the New. ${ }^{21}$ The Old Testament explicitly commands that a married woman who commits adultery should be killed for a capital offence (Lv 20:10, Dt 22:22) and that a girl who loses her virginity before marrying should be pelted with stones until she is dead (Dt 22:20-21). According to the Fourth Gospel, Jesus is of another opinion (Jn 8:1-11). Whatever one may think of the historical-critical problems presented by this passage and however one may celebrate the mysterious way in which Jesus outwitted the Pharisees, one point is clear: Jesus opposes practising the Torah. If only sinless people can execute the Law, it cannot be done. In this case Jesus shows dramatically that even the elite are sinners, but he is at the same time plainly critical of the Torah and prevents its enforcement. Now Childs (1992:98) does allow for this possibility, indeed he has to, because there are so many such cases in the New Testament, but he relativises it by making it only a descriptive task after which it will "be possible to turn to the larger task of trying to engage in theological reflection". This "reflection", it seems, has to argue that somehow the Torah is not undermined by the way Jesus handles it here and in the many other instances..$^{22} \mathrm{I}$ am not aware that Childs has done so, but in terms of the canon-as-text idea it will require squaring what Jesus says here with what he says elsewhere in the canon, namely that not one iota of the Law will remain unfulfilled (Mt 5:18). In the light of this part of the canon that would be up to Jesus himself, so his work entailed fulfilling all the iota's of the law, including those on stoning just married girls and executing adulterous people. So Jesus did not, after all, prevent the Old Testament part of the canon to be fulfilled when he stopped the lynching of the adulterous woman. Now this may sound like a caricature, but that is not my intention - it only illustrates what seems to me the unavoidable consequence of only allowing oneself a canon as a text to work with.

\footnotetext{
${ }^{21}$ For my present argument I shall not include a discussion of where the Old Testament material could have been relevant, but is ignored by the New Testament, which probably can be considered as a topic on its own (cf Barr 1999:421).

${ }^{22}$ Cf Mt 5:21f ("Überbietung”; not criticising something wrong in the Torah, but criticism by improving and extending it), Mt 5:27f (improving the Torah by making stricter what is written on adultery), Mt 5:38-41 (criticism of the lex talionis in Ex 21:24f, Lv 24:20 and Dt 19:21); Mt 12:1ff (Jesus as Lord of the Sabbath), Mt 5:43f (criticism of hatred and aggression towards enemies, cf Dt 23:6 - with far-reaching implications for prayers against enemies found in many laments in the Book of Psalms, e g Pss 70 and 137); cf also 1 Pt 3:9 etc.
} 
4.5 Different, but related is the use of the New Testament as a foil for getting past issues in the Old Testament perceived to be morally objectionable for Christians today. If this is done by appealing to the checks and balances provided by a canon containing both Testaments, it is in effect imitating what we have just seen the New Testament do, but with an appeal to the canon as text instead of an inherent authority. The New Testament brings us nowhere if we are opposed to slavery, since it accepts this social evil just as the Old Testament. And opposition to the death penalty fares little better, although it may be easier to construe something canonical as: the Old Testament commands the death penalty for certain offences, the New neither commands nor prohibits it (?), so we will have to use other arguments (to improve on our canon in the Old Testament), and this is allowed us by the New Testament's silence on the topic. Again, I am not suggesting that sophisticated scholars from the canonical fold actually do this kind of thing, I am only arguing that the canon as a connected text instead of a historical collection of authoritative books inculcates a system of checks and balances within the fabric of the one Scripture and therefore naturally invites a smoothing out effect. But the creases seem to in-crease. Scripture seems to shed as much shadow on itself as light.

\section{CONCLUSION}

The canon is there. It was there before it was made a book. The intertextual relationships between the New and the Old, whether critical or not, were in the New Testament before it was codexed. Therefore the relationship has to be considered also without the jacket. My objection is not that the canon is seen as a text, as a book now consisting of two Testaments, but that this becomes the only "correct" way to conceive of canon. Logically, if we wish to work with canon as a text, we will have to construe it. If we decide, as Childs does, for "the" Hebrew one, we will have to arrange our text so that it is structured that way. Then we will not be able to theologically use the identical structuring of the New Testament on the model of the Old Testament in its fourfold Septuagint arrangement: basic revelation (Pentateuch, Gospels), historical part (Joshua to Esther, Acts of the Apostles), books for life here and now (poetical and sapiential books, Pauline and other epistles), books for the future (prophets including Daniel, Revelation of John). Unless, of course, we construe a canon as it was done in one of the Reformation currents and use a hybrid of the Hebrew and the Greek canons together with the New Testament as one text. Something similar could be done in the Lutheran tradition, but with allowances for the so-called Apocrypha with their slightly higher status compared to the Calvinist tradition. And, again, the Roman Catholic canon already existing officially because the Pope declared it a canon - can be affirmed for this purpose. But then reflection is called for on the Roman 


\section{The canon as text for a biblical theology}

Catholic hybrids being used in actual practice (as illustrated well in works like Zenger \& Co's Introduction): are we really working with one book? Or are we constantly construing canons, on some occasions one at a time, on others rapidly after each other and then mixing them to obtain yet another de facto canon?

My submission is that this is what is being done in reality and, indeed, what has been going on for centuries. There have always been "final" texts seen as canons. And new "final" ones have not stopped being produced at the Reformation. Within the process of canon forming the same thing has been going on since the times in which the Old Testament itself was coming into being, as Dohmen \& Oeming have shown. And in the time of the nascent church, as the New Testament's use of the Old shows. And in so-called patristic times, as the many and varying canon lists in existence show. And in Judaism, as the different canonical orders in rabbinic discussions and the manuscript tradition show. ${ }^{23}$

Canon as a given in the theological tradition of Jews and Christians cannot be dispensed with. It is a historical given and necessary where theology is done with Holy Scriptures. But it has always appeared in different shapes and forms and sizes and is still doing so. Pointing as it does to the issues of variety and tensions and highlighting their theological relevance, it demonstrates its dynamic character. It is continually deconstructing and reconstructing itself as it has done in ancient Israel, in the many Jewish and Christian traditions and is still exercising the ferment as people today work with their own construed canons, whether overtly or covertly. To work in this broad stream with its many currents has a paradoxical effect. It is centripetal in that it draws together into one main stream, but it is also centrifugal in that the stream flows through history with its many landscapes and therefore different currents. It becomes a rapid, a maelstrom that cannot be navigated by a single steering technique. The idea of canon does not only permit, it requires different readings and therefore different reading strategies.

\section{Works consulted}

Bardtke, H 1964. Luther und das Buch Esther. Tübingen: J C B Mohr.

Barr, J 1983. Holy Scripture. Canon, authority, criticism. Philadelphia, PA: Westminster Press.

Barr, J 1999. The concept of biblical theology: An Old Testament perspective. Minneapolis, MN: Fortress Press.

Barton, J, Exum, J C \& Oeming, M (Hg). Das Alte Testament und die Kunst. Beiträge des Symposiums "Das Alte Testament und die Kultur der Moderne" anlässlich des 100. Geburtstags Gerhard von Rads (1901-1971), Heidelberg 18.-21. Oktober 2001. Münster: Lit Verlag. (Altes Testament und Moderne 15.)

\footnotetext{
${ }^{23}$ Cf for documentation and examples, Loader (2002a:739-753), as well as my paper at the Von Rad centenary 2001, Das Alte Testament - ein Geschichtsbuch? (in the press).
} 
Blum, E (Hg) 1990. Die hebräische Bibel und ihre zweifache Nachgeschichte. Festschrift R Rendtorff. Neukirchen-Vluyn: Neukirchener Verlag.

Bornkamm, H 1948. Luther und das Alte Testament. Tübingen: J C B Mohr.

Childs, B S 1970. Biblical theology in crisis. Philadelphia, PA: Westminster Press.

Childs, B S 1978. The exegetical significance of canon for the study of the Old Testament. VTS 29, 66-88.

Childs, B S 1979. Introduction to the Old Testament as Scripture. London: SCM Press.

Childs, B S 1985. Old Testament theology in a canonical context. London: SCM Press.

Childs, B S 1990. Analysis of a canonical formula: It shall be recorded for a future generation, in Blum (ed) 1990:357-364.

Childs, B S 1992. Biblical theology of the Old and New Testaments. London: SCM Press. (= Childs 1994, 1996.)

Childs, B S 1994. Die Theologie der einen Bibel. Band 1: Grundstrukturen. German translation of Childs (1992) by C Oeming. Freiburg: Herder.

Childs, B S 1996. Die Theologie der einen Bibel. Band 2: Hauptthemen. German translation of Childs (1992) by C \& M Oeming. Freiburg/Basel/Wien: Herder.

Dohmen, C \& Oeming, M 1992. Biblischer Kanon - warum und wozu? Eine Kanontheologie. Freiburg: Herder.

Coats, G W \& Long, B 1977. Canon and authority. Philadelphia, PA: Fortress Press.

Cross, F M (ed) 1976. Magnalia Dei: The mighty acts of God: G E Wright memorial volume. Garden City: Doubleday.

Gummelt, V 2000. Hollaz, David (1648-1713) und Hollaz, David (1704-1771), in Religion in Geschichte und Gegenwart 3. 4.Aufl, 1844. Tübingen: J C B Mohr.

Hanhart, R 1984. Die Bedeutung der Septuaginta in neutestamentlicher Zeit. ZThK 81, 395-416.

Jepsen, A 1949. Kanon und Text des Alten Testaments. ThLZ74, 66-74.

Jepsen, A 1957[1968]. Wissenschaft vom Alten Testament, in Westermann 1968:227-265 (= AVThR 1 1958:7-34).

Kraus, H-J 1969. Geschichte der historisch-kritischen Erforschung des Alten Testaments. Neukirchen-Vluyn: Neukirchener Verlag.

Kühlewein, J 1984. ספר sēfær Buch. THAT 2, 162-173.

Loader, J A 2002a. The finality of the Old Testament "final text". OTE 15/3, 739-753.7

Loader, J A 2002b. Tenach and Old Testament - the same Bible? HTS 58, 14151430.

Loader, J A 2005. Das Alte Testament - ein Geschichtsbuch? in Barton, Exum \& Oeming 2005:31-50.

Neusner, J 1990. The Midrash: An introduction. Northvale: Aronson.

Pelikan, J J 1947. Natural theology in David Hollaz. CTM 18, 253-263.

Sanders, J A 1972. Torah and canon. Philadelphia, PA: Fortress Press.

Sanders, J A 1976. Adaptable for life: The nature and function of canon, in Cross (ed) 1976:531-560.

Sanders, J A 1977. Hermeneutics in true and false prophecy, in Coats \& Long (eds) 1977, 21-41.

Schäfer, P 1975. Die sogenannte Synode von Jabne: Zur Trennung von Juden und Christen im ersten/zweiten Jh. n.Chr, Judaica 31, 116-124.

Steins, G 1996. Torabindung und Kanonabschluß: Zur Entstehung und kanonischen Funktion der Chronikbücher, in: Zenger (Hrsg) 1996b:213-256. 
Stendahl, K 1962. Biblical Theology. IDB 1, 418-432.

Sundberg, A C 1964. The Old Testament of the early church. Cambridge, MA: Harvard University Press.

Sundberg, A C 1975. The Bible canon and the Christian doctrine of inspiration. Int 29, 352-371.

Westermann, C 1968. Probleme alttestamentlicher Hermeneutik: Aufsätze zum Verstehen des Alten Testaments. München: Chr Kaiser Verlag. (ThB 11.)

Wildeboer, G [1889]1908. Het ontstaan van den kanon des Ouden Verbonds: Historisch-kritisch Onderzoek. 4th ed. Groningen: Wolters.

Zahavy, T 1994. Biblical Criticism: Midrash and Medieval Commentary, in Groden, M \& Kreisworth, M (eds), Johns Hopkins guide to literary theory and criticism. Electronic publication 2 July 2005: http://tzvee.com/bibcrit.htm.

Zenger, E e a 1996a. Einleitung in das Alte Testament. Stuttgart: W Kohlhammer. Zenger, E (Hg) 1996b. Die Tora als Kanon für Juden und Christen. Freiburg: Herder. (Herders Biblische Studien 10.) 